\title{
Role of embryonic oestrogen in rabbit blastocyst development and metabolism*
}

\author{
B. C. Paria, Jayasree Sengupta and S. K. Manchanda \\ Department of Physiology, All India Institute of Medical Sciences, New Delhi 110029, India
}

\begin{abstract}
Summary. Rabbit morulae were grown for $24 \mathrm{~h}$ in Ham's F12 medium supplemented with BSA. CI-628 citrate $(1.5 \mu \mathrm{g} / \mathrm{ml})$, a specific oestrogen antagonist, significantly inhibited the transformation of morulae to blastocysts. This inhibition was reversed with oestradiol-17 $\beta(1 \mu \mathrm{g} / \mathrm{ml})$ but not oestradiol-17 $\alpha(1 \mu \mathrm{g} / \mathrm{ml})$ added to the culture medium. The specific activities of phosphof ructokinase, lactic dehydrogenase, malate dehydrogenase and alkaline phosphatase in blastocysts grown in vitro for $24 \mathrm{~h}$ in medium TC 199 + BSA showed significant elevation with blastocyst growth and expansion, while that of acid phosphatase revealed no change, and leucine aminopeptidase activity declined significantly. These changes were markedly inhibited by CI-628 citrate $(2 \mu \mathrm{g} / \mathrm{ml})$ and were reversed by oestradiol- $17 \beta(0.4 \mu \mathrm{g} / \mathrm{ml})$ but not by oestradiol- $17 \alpha(0 \cdot 4 \mu \mathrm{g} / \mathrm{ml})$. Our findings suggest a role of oestrogen present in the rabbit morula and blastocyst in the triggering of embryonic differentiation and metabolic functions.
\end{abstract}

\section{Introduction}

The role of steroids in the preimplantation embryo or at the time of implantation is an issue of considerable debate. Mammalian embryos have been shown to possess the steroidogenic enzymes, $\Delta^{5}, 3 \beta$-hydroxysteroid dehydrogenase $\left(\Delta^{5}, 3 \beta\right.$-HSD) and $17 \beta$-hydroxysteroid dehydrogenase (17 $\beta$ HSD) first detected histochemically (Dickmann, Dey \& Sengupta, 1976). Biochemically, 17 $\beta-H S D$ was detected by the conversion of $\left[{ }^{3} \mathrm{H}\right]$ oestradiol- $17 \beta$ to $\left[{ }^{3} \mathrm{H}\right]$ oestrone in mouse and rat blastocysts grown in vitro ( $\mathrm{Wu} \& \mathrm{Lin}, 1982 \mathrm{a}$ ). The rabbit blastocyst has been extensively analysed. Progesterone and oestradiol-17 $\beta$ contents of rabbit blastocysts at Days 5 and 6 post coitum (p.c.) have been reported (Seamark \& Lutwak-Mann, 1972; Fuchs \& Beling, 1974; Dickmann et al., 1975), but it has been suggested that these steroids may be of maternal origin (Borland, Erickson \& Ducibella, 1977; Singh \& Booth, 1978). Evidence showing lack of $\Delta^{5}, 3 \beta-H S D$ and steroid hormones in the preimplantation rabbit blastocyst has also been reported (Gadsby, Heap \& Burton, 1980; Bleau, 1981). However, biochemical evidence in support of oestradiol synthesis from testosterone and androstenedione in blastocysts grown in vitro suggests that the aromatase enzyme system is present in rabbit blastocysts at Days 5-6 p.c. (George \& Wilson, 1978; Hoversland, Dey \& Johnson, 1982; Wu \& Lin, 1982b). In the present study we have investigated whether embryonic steroids are required to support differentiation and metabolism in the rabbit embryo.

\footnotetext{
* Reprint requests to Dr J. Sengupta.
} 


\section{Materials and Methods}

Mature, New Zealand White, virgin rabbits were housed in individual cages in a room with natural lighting conditions and constant temperature $\left(23^{\circ} \mathrm{C}\right)$. Rabbits were induced to superovulate (Kane \& Foote, 1965) with FSH (Sigma, St Louis, MO, U.S.A.), 0.1 mg being injected twice daily for 3 days. The does were mated with 2 fertile bucks in rapid succession and injected i.v. with 25 i.u. hCG (Ayerst, New York, U.S.A.). The day of mating was considered as Day 0 of pregnancy.

\section{Experiment I: study of morula to blastocyst transformation}

Rabbits were killed on the morning $(07: 00-08: 00 \mathrm{~h})$ of Day 3 and their reproductive tracts were flushed with pre-warmed, sterile Ham's F12 medium (Gibco, New York, U.S.A.) supplemented with $0.5 \%$ bovine serum albumin (Sigma). All embryos were at the morula stage; they were washed 3 times in sterile medium and then placed in culture. The culture was performed in rubberstoppered, sterile $10 \times 75 \mathrm{~mm}$ Kimax tubes containing $1 \mathrm{ml}$ sterile Ham's F12-BSA medium. The gas phase was $5 \% \mathrm{CO}_{2}$ and $95 \%$ air and the tubes were kept in a humid atmosphere at $37^{\circ} \mathrm{C}$. The morulae recovered on Day 3 were randomly assigned to one of 4 groups.

Group 1: morulae were grown in $1 \mathrm{ml}$ culture medium containing $1 \mu \mathrm{l}$ saline $(0.9 \% \mathrm{w} / \mathrm{v} \mathrm{NaCl})$ and $5 \mu \mathrm{l}$ ethanol-saline $\left(2.83 \times 10^{-5} \mathrm{M}\right.$-alcohol $)$ which had been passed through a $0.22 \mu \mathrm{m}$ millipore filter to ensure sterility.

Group 2: morulae were exposed to $1.5 \mu \mathrm{g}$ CI-628 citrate $\left(4.07 \times 10^{-6} \mathrm{M}\right.$; Parke Davis Co., Detroit, MI, U.S.A.), a non-steroidal oestrogen antagonist, dissolved in $1 \mu \mathrm{l}$ saline per ml culture medium and $5 \mu$ l ethanol-saline.

Group 3: morulae were exposed to the same concentration of CI-628 citrate as in Group 2 and, in addition, the culture medium contained $1 \mu \mathrm{g}$ oestradiol-17 $\beta\left(3.67 \times 10^{-6} \mathrm{M}\right.$; Sigma $)$ dissolved in $5 \mu \mathrm{l}$ ethanol-saline.

Group 4: morulae were grown in $1 \mathrm{ml}$ culture medium containing CI-628 citrate in the same concentration as in Groups 2 and 3 ; in addition, $1 \mu \mathrm{g}$ oestradiol-17 $\alpha\left(3.67 \times 10^{-6} \mathrm{M}\right.$; Sigma) dissolved in $5 \mu$ l ethanol-saline was added to the medium.

At the end of $24 \mathrm{~h}$ all cultures were terminated and the embryos, recovered in Falcon plastic dishes, were examined under a stereozoom microscope to assess their development. All results were subjected to statistical analysis using the $\chi^{2}$ test (Hill, 1966).

\section{Experiment II: study of blastocyst metabolism}

Rabbits were killed on the morning (09:00 h) of Day 6 and their uteri were flushed with prewarmed, sterile TC 199 medium (Bios, Bombay, India). The blastocysts were rapidly washed in fresh medium and examined under the stereozoom microscope to measure embryo diameters. The blastocysts were then cultured in 10-ml sterile, rubber-stoppered, Erlenmeyer flasks containing 5 $\mathrm{ml}$ sterile TC 199 medium supplemented with $0.1 \%$ BSA. Each flask had a gas phase of $5 \% \mathrm{CO}_{2}$ and $95 \%$ air, and contained 5 or 6 blastocysts. The flasks were kept in a humid chamber maintained at $37^{\circ} \mathrm{C}$. The collected blastocysts were randomly assigned to one of 5 groups.

Group 1: the blastocysts were not placed in culture but were immediately homogenized for biochemical estimation of enzyme activities.

Group 2: blastocysts were grown in TC 199 medium containing $50 \mu$ l ethanol-saline $(28 \cdot 3 \times$ $10^{-5} \mathrm{M}$ ) and $10 \mu \mathrm{l}$ saline sterilized by passage through a $0.22 \mu \mathrm{m}$ millipore filter.

Group 3 : blastocysts were divided into three subgroups and exposed to $1.0 \mu \mathrm{g}\left(2 \cdot 7 \times 10^{-6} \mathrm{M}\right), 1 \cdot 5$ $\mu \mathrm{g}\left(4.07 \times 10^{-6} \mathrm{M}\right)$ or $2.0 \mu \mathrm{g}\left(5.43 \times 10^{-6} \mathrm{M}\right) \mathrm{CI}-628$ citrate, dissolved in $10 \mu \mathrm{l}$ saline, per $\mathrm{ml} \mathrm{TC} 199$ medium.

Group 4 : blastocysts were divided into 2 subgroups: in the first subgroup the blastocysts were grown in $5 \mathrm{ml} \mathrm{TC} 199$ medium containing $2.0 \mu \mathrm{g} \mathrm{CI}-628$ citrate in $10 \mu \mathrm{l}$ saline $/ \mathrm{ml}$ and $1.0 \mu \mathrm{g}$ 
oestradiol-17 $\left(3.64 \times 10^{-6} \mathrm{M}\right)$, dissolved in $50 \mu$ l ethanol-saline, and in the second subgroup the same concentration of the antagonist plus $2.0 \mu \mathrm{g}$ oestradiol- $17 \beta\left(7.34 \times 10^{-6} \mathrm{M}\right)$ in same volume of vehicle was used.

Group 5 : blastocysts were exposed to $2.0 \mu \mathrm{g}$ CI 628 citrate, dissolved in $10 \mu \mathrm{l}$ saline per $\mathrm{ml}$, and $2.0 \mu$ g oestradiol- $17 \alpha\left(7.34 \times 10^{-6} \mathrm{M}\right)$, dissolved in $50 \mu$ lethanol-saline, in $5 \mathrm{ml}$ TC 199 medium.

All cultures were terminated after $24 \mathrm{~h}$ and the recovered blastocysts were quickly examined under the stereozoom microscope to determine their condition and extent of expansion by measuring their diameters. Blastocysts were washed well with cold saline and then $3-5$ blastocysts were homogenized in an all-glass homogenizer using $1 \mathrm{ml}$ cold sucrose $(0 \cdot 25 \mathrm{M})$. Aliquants were taken from supernatant fractions for the enzyme assays.

Six enzymes were studied. Phosphofructokinase (EC 2.7.1.11) activity was measured by the method of Ling, Paetkau, Marcus \& Lardy (1966) but the incubation volume was reduced to $1 \mathrm{ml}$. Lactate dehydrogenase (EC 1.1.1.27) activity was measured by the method of Brinster (1965). Malate dehydrogenase (EC 1.1.1.37) activity was measured using the method described in the Information Bulletin published by Boehringer-Mannheim, Germany (1973) but the total volume of incubation mixture was reduced to $1 \mathrm{ml}$. The linear decrease in absorbance at $340 \mathrm{~nm}$ during the first $15 \mathrm{~min}$ was used to calculate the activity of the enzymes and $\mu \mathrm{mol} \mathrm{NADH}$ oxidized/min was used to express the total enzyme activity. Acid and alkaline phosphatase activities (EC 3.1.3.2 and EC 3.1.3.1) were measured using the method of Linford \& Iosson (1975). One phosphatase unit was defined as that amount of enzyme activity which liberated $1 \mu \mathrm{mol} p$-nitrophenol/h under the stated test conditions. The activity of leucine aminopeptidase (EC 3.4.11.1) was measured as described by Goldberg \& Rutenburg (1958) but the total reaction volume was reduced to $1 \mathrm{ml}$. One unit of leucine aminopeptidase will release $1 \mu \mathrm{mol} \beta$-naphthylamine from its substrate per hour at $37^{\circ} \mathrm{C}$ and $\mathrm{pH}$ $7 \cdot 1$.

The DNA content of the blastocysts was estimated according to the method of Burton (1956), but the total volume of the reaction mixture was reduced to $1.5 \mathrm{ml}$. All enzyme activities were expressed both on a per blastocyst and on a per $\mu \mathrm{g}$ DNA basis. All enzyme assays were linear with time and increasing enzyme activity.

For statistical purposes we performed one-way analysis of variance and then applied Duncan's Multiple range test (Federer, 1955) to compare the significance of the differences between means of enzyme activities.

\section{Results}

\section{Morula to blastocyst transformation}

The effects of CI-628 citrate on rabbit embryo development at the time of morula to blastocyst transformation are shown in Table 1. CI-628 citrate significantly reduced the development of blastocysts from the morula stage, but this effect was reversed in Group 3. Oestradiol-17 $\alpha$ was not able to reverse the effect of CI-628 citrate.

\section{Blastocyst metabolism}

The effects of different steroids and/or non-steroidal antagonist-containing media on blastocyst growth and expansion during 24-h culture showed that the BSA-supplemented medium TC 199 plus ethanol and saline led to significant $(P<0.001)$ expansion in 62 of the $70(88.6 \%)$ blastocysts cultured (12 replicate cultures). A distinct dose-specific response was obtained after exposure to CI628 citrate; at $1.0 \mu \mathrm{g} / \mathrm{ml}$ there was a reduction in embryo expansion $(27 / 39,68 \%, 8$ replicates; $P<$ $0.05)$, but at $1.5 \mu \mathrm{g} / \mathrm{ml}$ only $15 / 28(52 \%)$ blastocysts expanded (6 replicates) $(P<0.001)$ and at 2.0 $\mu \mathrm{g} / \mathrm{ml}$ the values were $11 / 80(13 \%, 14$ replicates $P<0.001)$. The blastocysts that had not expanded showed no degeneration. A dose-dependent response was obtained when the CI-628 citrate- 
Table 1. Effects of CI-628 citrate and oestrogens on rabbit embryo development in vitro

\begin{tabular}{|c|c|c|c|c|}
\hline Group & $\begin{array}{l}\text { Steroids in culture } \\
\text { medium }(\mu \mathrm{g} / \mathrm{ml})\end{array}$ & $\begin{array}{c}\text { No. of morulae } \\
\text { cultured } \\
\text { (no. of replicates) }\end{array}$ & $\begin{array}{c}\text { No. of } \\
\text { blastocysts } \\
\text { developed } \\
\text { after } 24 \mathrm{~h}(\%)\end{array}$ & $\begin{array}{c}\text { No. of } \\
\text { morulae } \\
\text { after } \\
24 \mathrm{~h}(\%)\end{array}$ \\
\hline 1 & - & $63(15)$ & $51(81 \cdot 0)$ & $12(19 \cdot 1)$ \\
\hline 2 & CI-628 citrate $(1 \cdot 5)$ & $49(12)$ & $9(18.4)^{*}$ & $40(81 \cdot 6)$ \\
\hline 3 & CI-628 citrate $(1.5)$ & & & \\
\hline \multirow{3}{*}{4} & + oestradiol-1 $7 \beta$ (1) & $41(10)$ & $31(75 \cdot 6) \dagger$ & $10(24.4)$ \\
\hline & Cl-628 citrate $(1.5)$ & & & \\
\hline & + oestradiol $-17 \alpha(1)$ & $35(8)$ & $5(14 \cdot 2)^{*}$ & $30(85 \cdot 7)$ \\
\hline
\end{tabular}

$* P<0.001$ compared with Group 1 .

$\dagger P<0.001$ compared with Group 2.

induced inhibition of blastocyst expansion was reversed by culture with oestradiol-17 $\beta:$ at $0.2 \mu \mathrm{g} / \mathrm{ml}$ $43.3 \%$ blastocysts (13/30, 6 replicates) showed expansion $(P<0.001$ compared with control value), but at $0.4 \mu \mathrm{g} / \mathrm{ml} \mathrm{79/93}(84.95 \%, 18$ replicates) blastocysts expanded $(P<0.05$ compared with control value). Oestradiol-17 $\alpha$ had no effect on blastocyst growth in the presence of CI-628 citrate and only $11 / 81(13.6 \%, 16$ replicates $)$ blastocysts expanded.

\section{Enzlme acticities}

The activities of the 3 carbohydrate, 2 lysosomal enzymes and alkaline phosphatase are given in Table 2. A comparison of the enzyme activities obtained in Day 6 p.c. blastocysts (Group 1) with the enzyme levels obtained after $24 \mathrm{~h}$ in culture (Group 2) revealed significant increases in the activities of all the enzymes except leucine aminopeptidase. There was an associated increase in blastocyst DNA content. The activity of leucine aminopeptidase, when expressed per $\mu \mathrm{g}$ DNA, showed a significant decline during culture for $24 \mathrm{~h}$. Exposure to CI-628 citrate (Group 3c) led to drastic reduction in the activities of all the enzymes and the values were not different from those found in Group 1. Addition of oestradiol-17 (Group 4b), but not its inactive isomer, oestradiol-17 $\alpha$ (Group 5), resulted in marked reversal in enzyme levels with higher DNA content. These results indicate that exposure to the oestrogen antagonist led to suppression of blastocyst growth and metabolism and that effective reversal of this inhibition was obtained only with oestradiol-17 $\beta$.

\section{Discussion}

Preimplantation mammalian embryo development in vitro parallels the changes that occur in normally fertilized embryos grown entirely in vivo (Van Blerkom \& Runner, 1976). In the rabbit, the fine structural changes that occur in membrane structure, mitochondrial configuration and formation of functional complexes in trophectoderm cells and the qualitative changes in protein synthesis at the time of blastocyst formation are identical in embryos grown in vivo and in vitro (Van Blerkom \& Manes, 1977). The embryo developing in vitro is therefore very useful for study of cellular control mechanisms outside the influence of the maternal environments. In the present study on the role of endogenous oestrogen on embryonic differentiation and blastocyst metabolism, CI-628 citrate significantly prevented the transformation of rabbit morulae into blastocysts in vitro. This drug is a well known oestrogen antagonist and it prevents hormone action by binding to cytosolic receptors for oestradiol (Katzenellenbogen, Katzenellenbogen, Ferguson \& Krauthammer, 1978). CI-628 citrate can translocate the oestrogen receptor to the nucleus (Clark, Peck \& Anderson, 1974), but receptor replenishment does not occur (Sutherland \& Murphy, 1982). It has 


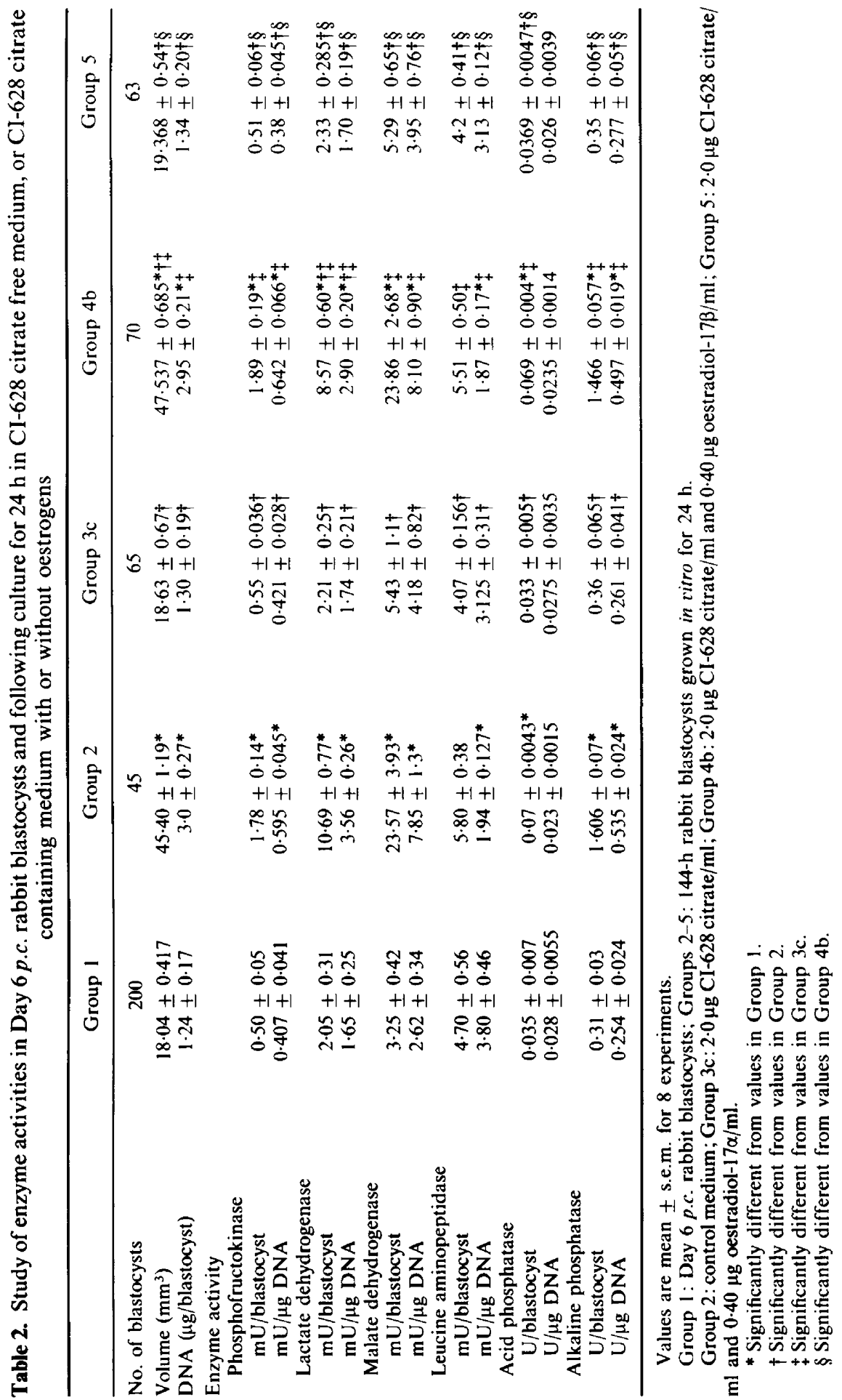


been suggested that there are antioestrogen-specific binding sites that do not compete with oestrogen receptor sites in a wide variety of oestrogen target and non-target tissues (Sutherland \& Murphy, 1980; Sudo, Monsma \& Katzenellenbogen, 1983). In the rat uterus, non-steroidal antagonists are partial agonists and partial antagonists, but there is considerable evidence that antioestrogens are antagonists in vitro under conditions in which metabolic conversions do not occur (Hayes, Rorke, Robertson, Katzenellenbogen \& Katzenellenbogen, 1981).

The inhibitory effect of CI-628 citrate on blastocyst formation appeared to be due to a specific inhibition of oestrogen function since only oestradiol-17 $\beta$ was able to reverse completely this response of the drug. During late cleavage increased protein synthesis and growth initiated at the blastocyst stage are dependent upon ATP generation (Ginsberg \& Hillman, 1975), changes in the profile of metabolic pathways (Epstein, 1975) and activation of sodium-dependent transport systems (Borland \& Tasca, 1974). Embryo oestrogen may regulate one or more of these cellular events. The present finding of an oestrogen requirement during blastocyst formation is consistent with our earlier reports for mouse (Sengupta, Roy \& Manchanda, 1982), rat (Roy, Sengupta \& Manchanda, 1981) and hamster (Sengupta, Paria \& Manchanda, 1983) embryos.

In the rabbit embryo, carbohydrate metabolism during the preblastocyst stage proceeds mainly via the pentose phosphate shunt pathway and, once the blastocyst stage is reached, there is a shift in the metabolic pathway towards the glycolytic and TCA cycle (Friedhandler, 1961). Mukherjee, Dey, Sengupta, Ramadoss \& Dickmann (1978) obtained a pronounced increase in the activities of two rate-limiting enzymes, phosphofructokinase and pyruvate kinase, of the glycolytic cycle in Day 6 rabbit blastocysts grown in vitro for $24 \mathrm{~h}$. The present study confirms this observation and indicates an increase in the specific activities of phosphofructokinase, lactate dehydrogenase and malate dehydrogenase in rabbit blastocysts of similar age grown in culture for $24 \mathrm{~h}$. Our findings suggest an increased synthesis of these enzymes of the energy-generating pathways to facilitate cellular growth and development. The enhanced energy requirements and metabolic function were shown from the ADP and ATP levels which doubled every $9 \mathrm{~h}$ in 5-6-day rabbit blastocysts (Brooks \& Lutwak-Mann, 1971). Benos \& Balaban (1980) also reported increased $Q \mathrm{O}_{2}$ in developing rabbit blastocysts and have suggested an aerobic dependence of active transepithelial ion transport during blastocyst expansion. We have studied the activity of alkaline phosphatase, another membranebound enzyme, and report enhanced specific activity of the enzyme with blastocyst development and expansion in culture. It has been suggested that this enzyme is involved in membrane transport processes (Fernley, 1971).

Lysosomes have been identified in trophoblast cells and several lysosomal enzymes have been detected in mammalian embryos during the preimplantation stages, but their role during early embryogenesis remains to be understood. Denker (1982) detected arylamidase, a proteinase, in rabbit blastocysts and suggested that it may play a role in the dissolution of the mucin coat. Rat trophoblast maturation and blastocyst expansion in vitro has been associated with the changes in the levels of acid phosphatase and leucine aminopeptidase (Roy, Sengupta, Paria \& Manchanda, 1982). The significance of the reduced activity of leucine aminopeptidase in rabbit blastocysts remain to be defined.

The regulation of metabolic pathways in mammalian embryos can result from pre-programmed genetically derived controls and/or be influenced by hormones, activators or inhibitors present in the blastocyst or the surrounding uterine milieu. Oestrogen can induce the de-novo synthesis of phosphofructokinase, pyruvate kinase and lactate dehydrogenase (Singhal, Valadares \& Ling, 1967; Singhal \& Valadares, 1970; Clark \& Yochim, 1971) in the rat uterus. The rabbit blastocyst contains oestradiol- $17 \beta$ and the enzyme system for aromatization of androgens to oestrogen (Dickmann et al., 1975; Singh \& Booth, 1978; George \& Wilson, 1978; Hoversland et al., 1982; Wu $\&$ Lin, 1982b). The present communication has presented evidence which suggests that embryonic oestrogen is required to stimulate metabolic functions in the blastocyst, and that the higher specific activities of phosphof ructokinase, lactate dehydrogenase and malate dehydrogenase with growth depend on the presence of adequate amounts of this steroid. A characteristic dose-dependent effect 
was obtained with the inhibitory response of the oestrogen antagonist on blastocyst growth and metabolic processes, and in the reversal of the response with oestradiol-17 $\beta$. It is very likely that the earlier reports on failure of exogenously administered oestradiol-17 $\beta$ in stimulating RNA synthesis in mouse preimplantation embryos (Warner \& Tollefson, 1978) and activation of enzymes of carbohydrate and energy generating pathways (Mukherjee et al., 1978) in rabbit blastocysts could be due to embryonic refractoriness.

In conclusion we suggest that oestrogen present in the preimplantation rabbit embryo is essential for supporting early embryonic differentiation, and metabolic functions in the blastocyst.

This study was supported by funds from the All India Institute of Medical Sciences, the Indian Council of Medical Research, and the Family Planning Foundation of India. We thank Parke Davis, U.S.A., for the generous gift of CI-628 citrate.

\section{References}

Benos, D.J. \& Balaban, R.S. (1980) Energy requirements of the developing mammalian blastocyst for active ion transport. Biol. Reprod. 23, 941-947.

Bleau, G. ( 1981 ) Failure to detect $\Delta^{5} 3 \beta$ hydroxy-steroid oxidoreductase activity in the preimplantation rabbit embryo. Steroids 37, $121-132$.

Borland, R.M. \& Tasca, R.J. (1974) Activation of $\mathrm{Na}^{+}$ dependent amino acid transport system in preimplantation mouse embryos. Devl Biol. 36, 169-182.

Borland, R.M., Erickson, G.F. \& Ducibella, T. (1977) Accumulation of steroids in rabbit preimplantation blastocysts. J. Reprod. Fert. 49, 219-224.

Brinster, R.L. (1965) Lactate dehydrogenase activity in the preimplantation mouse embryo. Biochim. Biophys. Acta 110, 439-441.

Brooks, D.E. \& Lutwak-Mann, C. (1971) Content of ATP and ADP in rabbit blastocyst. Nature, Lond. 229. 202-203.

Burton, K. (1956) A study of the conditions and mechanisms of the diphenyl-amine reaction for the colorimetric estimation of deoxyribo nucleic acid. Biochem. J. 62, 315-323.

Clark, J.H., Peck, E.J. \& Anderson, J.N. (1974) Oestrogen receptors and antagonism of steroid hormone action. Nature, Lond. 251, 446-448.

Clark, S.W. \& Yochim, J.M. (1971) Effect of ovarian steroids on lactic dehydrogenase activity in endometrium and myometrium of the rat uterus. Endocrinolog. 89, 358-365

Denker, H.W. (1982) Proteases of the blastocyst and of the uterus. In Proteins and Steroids in Early Pregnancy, pp. 183-208. Eds H. M. Beier \& P. Karlson. Springer-Verlag, Berlin.

Dickmann, Z., Dey, S.K. \& Sengupta, J. (1975) Steroidogenesis in rabbit preimplantation embryos. Proc. natn. Acad. Sci. U.S.A. 72, 298-300.

Dickmann, Z., Dey, S.K. \& Sengupta, J. (1976) A new concept: control of early pregnancy by steroid hormones originating in the preimplantation embryos. Vitams Horm. 34, 215-242.

Epstein, C.J. (1975) Gene expression and macromolecular synthesis during preimplantation embryonic development. Biol. Reprod. 12, 82-105.

Federer, W.T. (1955) Experimental Design. Macmillan. New York.
Fernley, H. (1971) Mammalian alkaline phosphatases. In The Enzlmes, Vol. 4, pp. 417-447. Ed. P. D. Boyer. Academic Press. London.

Friedhandler, L. (1961) Pathways of glucose metabolism in fertilized rabbit ova at various preimplantation stages. Expl Cell Res, 22, 303-316.

Fuchs, A.R. \& Beling, C. (1974) Evidence for early ovarian recognition of blastocysts in rabbits. Endocrinolog. 95, 1054-1058.

Gadsby, J.E., Heap, R.B. \& Burton, R.D. (1980) Oestrogen production by blastocyst and embryonic tissue of various species. J. Reprod. Fert. 60, 409-417.

George, F.W. \& Wilson, J.D. (1978) Estrogen formation in the early rabbit embryo. Science. N.Y. 199, 200201.

Ginsberg, L. \& Hillman, N. (1975) Shifts in ATP synthesis during preimplantation stages of mouse embryos. J. Reprod. Fert. 43, 83-89.

Goldberg, J.A. \& Rutenburg, A.M. (1958) The colorimetric determination of leucine amino-peptidase in urine and serum of normal subjects and patients with cancer and other diseases. Cancer 11, 238-291.

Hayes, J.R., Rorke, E.A., Robertson, D.W., Katzenellenbogen, B.S. \& Katzenellenbogen, J.A. (1981) Biological potency and uterine estrogen receptor interactions of the metabolites of the anti-estrogens CI-628 and U23, 469. Endocrinology 108, 164-172.

Hill, A.B. (1966) Principles of Medical Statistics. The English Language Book Society and the Lancet Limited, Great Britain.

Hoversland, R.C., Dey, S.K. \& Johnson, D.C. (1982) Aromatase activity in the rabbit blastocyst. $J$. Reprod. Fert. 66, 259-263.

Kane, J.J. \& Foote, R.H. (1965) Superovulatory response of pre- and post-pubertal rabbits to commercially available gonadotrophins. J. Reprod. Fert. 9, 177188.

Katzenellenbogen, B.S., Katzenellenbogen, J.A., Ferguson, E.R. \& Krauthammer, N. (1978) Anti-oestrogen interaction with uterine oestrogen receptors. Studies with a radiolabelled anti-oestrogen (CI-628). J. biol. Chem. 253, 697-707.

Linford, E. \& Iosson, J.M. (1975) A quantitative study of some lysosomal enzymes in the bovine endometrium during early pregnancy. J. Reprod. Fert. 44, 249-260. 
Ling, K.H., Paetkau, V., Marcus, F. \& Lardy, H.A. (1966) Phosphofructokinase. In Methods in Enzymology, Vol. IX, pp. 425 429. Ed. W. A. Wood. Academic Press, New York.

Mukherjee, A., Dey, S.K., Sengupta, J., Ramadoss, C.S. \& Dickmann, Z. (1978) Regulatory enzymes of carbobydrate and energy metabolism in the rabbit blastocyst. J. Reprod. Fert. 53, 77-80.

Roy, S.K., Sengupta, J. \& Manchanda, S.K. (1981) Rat embryo development in ritro. Acta endocr.. Copenh. 96, $546-55 \mathrm{I}$.

Roy, S.K., Sengupta, J., Paria, B.C. \& Manchanda, S.K. (1982) In-vitro inhibition of trophoblast maturation and expansion of early rat blastocysts by an oestrogen antagonist. Acta endocr., Copenh. 99. 129-135

Seamark, R.F. \& Lutwak-Mann, C. (1972) Progestin in rabbit blastocysts. J. Reprod. Fert. 29, 147-149.

Sengupta, J., Roy, S.K. \& Manchanda, S.K. (1982) Effect of an oestrogen synthesis inhibitor, 1.4,6-androstatriene-3.17-dione, on mouse embryo development in titro. J. Reprod. Fert. 66, 63-66.

Sengupta, J., Paria, B.C. \& Manchanda, S.K. (1983) Effect of an oestrogen antagonist on development of blastocysts and implantation in the hamster. $J$. exp. Zool. 225, 119-122.

Singh, M.M. \& Booth, W.D. (1978) Studies on the metabolism of neutral steroids by preimplantation rabbit blastocysts in ritro and the origin of blastocyst oestrogen. J. Reprod. Fert. 53, 297-304.

Singhal, R.L. \& Valadares, J.R.E. (1970) Estrogen regulation of uterine pyruvate kinase. Am. J. Physiol. 218, 321-327.
Singhal, R.L., Valadares, J.R.E. \& Ling, G.M. (1967) Metabolic control mechanisms in mammalian system. I. Hormonal induction of phosphofructokinase in the rat uterus. $J$. biol. Chem. 242, 2593-2598.

Sudo, K., Monsma, F.J., Jr \& Katzenellenbogen, B.S. (1983) Antiestrogen-binding sites distinct from the estrogen receptor: subcellular localization, ligand specificity, and distribution in tissues of the rat. Endocrinology 112, 425-434.

Sutherland, R.L. \& Murphy, L.C. (1980) The binding of tamoxifen to human mammary carcinoma cytosol. Eur. J. Cancer 16, 1141-1148.

Sutherland, R.L. \& Murphy, L.C. (1982) Mechanisms of estrogen antagonism by nonsteroidal anti-estrogens. Molec cell. Endoc. 25, 5-23.

Van Blerkom, J. \& Manes, C. (1977) The molecular biology of the preimplantation embryo. In Concepts in Mammalian Embryogenesis, pp. 37-94. Ed. M. J. Sherman. M.l.T. Press, Cambridge.

Van Blerkom, J. \& Runner, M.N. (1976) The fine structural development of preimplantation mouse parthenotes. J. exp. Zool. 196, 113-123.

Warner, C.M. \& Tollefson, C.M. (1978) The effect of progesterone, estradiol and serum on RNA synthesis in preimplantation mouse embryo cultured in titro. Biol. Reprod. 19, 332-337.

Wu, J.T. \& Lin, G.M. (1982a) The presence of $17 \beta-$ hydroxysteroid dehydrogenase activity in preimplantation rat and mouse blastocysts. J. exp. Zool. 220 , 121-124.

Wu, J.T. \& Lin, G.M. (1982b) Effect of aromatase inhibitor on oestrogen production in rabbit blastocysts. J. Reprod. Fert. 66, 655-662.

Received 9 June 1983 